\title{
THE MUSEUM OF NOTHING
}

\author{
But is it art?
}

\section{BY ANNA ZUMBRO}

$\mathrm{T}$ he first thing they ask at the Museum of Nothing is that you remove your contact lenses. They even have cases and little bottles of solution, free of charge, although considering how much tickets cost, I suppose it's a stretch to say they're giving you anything for free.

"I have astigmatism," I say when the guard asks if I'm wearing smart lenses. "They're for a prescription." They're also for augmentation, of course, like everybody else's, which is the real reason the museum requires you to leave them behind.

The guard is unmoved. "It's the Museum of Nothing," she says pointedly. "It's not like you'll be missing out."

She meets my eyes, allowing my lenses to get a good read on her. Her name is Wanda Richardson and she lives on Webster Street. She dropped out of high school at sixteen, joined a gang and spent nine months in prison for conspiracy to commit robbery, although all she did was act as lookout while her friends bashed in the door to the electronics shop. A church mission helped her turn her life around, until she had an affair with the mission's pastor. She found a second chance - or third, perhaps - as a guard at the museum.

Wanda's eyes narrow. She knows I'm looking at her bio feed that's being projected by my lenses, that I'm processing her past. She isn't wearing lenses, though. Apparently even the guards have to follow the rules here. Seems foolish. You'd think the guards would know better whom to watch if they had lenses feeding them information on the patrons. But then, if it really is the Museum of Nothing, I guess there's nothing to steal.

I write my name on the bag Wanda gives me and remove my lenses at the small sink next to her desk. Her face blurs. She points at the entrance to the exhibition, and I put my hand out in case my eyes fail me.

The gallery has white walls and wooden floors, just like the other galleries I've been to, the ones with Da Vincis and Kahlos and Wyeths and all the rest. But here, there are no paintings, no sculptures, nothing but four white walls and a plaque next to the door. I squint to read the plaque: Please do not touch the artwork. And I start to laugh. I can't help it. There's nothing here.

him. "I came to see the art."

Now I know something's not right. I step backward. "Sure," I say, humouring him. "It's like nothing I've ever seen."

"No, no. Don't misunderstand," he rushes. "I'm not saying the wall is art. But what is art for, if not to make you think? All day long we're fed information. We never have to figure anything out. Don't you see? This place makes you think. It sparks the imagination. That's why it's art."

I follow his gaze to the wall. If there's any texture in the paint, I can't make it out. All I can think is that I wish I had my contacts back. The world feels strange without them.

"I never thought of myself as old-fashioned before," I say, "but I've always preferred art that I can actually see."

The man steps closer to the wall and leans forward. "Perhaps you should look again," he says. "I recognize this one. Spilled Milk on White Marble."

"Is it, now?" I say. "I had confused it for that other masterpiece, Invisible Ghosts Dancing in Fog."

We both laugh. His is a nervous laugh, which sets me at ease. I wonder what he sus-

"So, what brought you to the museum?" asks a man about my height. He smiles as he says this. I think he's amused with me, not at me. But it's hard to tell. His features are blurry, almost abstract. I shiver as I realize that without my lenses I don't know his name or his background, don't know if he volunteers at the soup kitchen every Thursday or is on the run from a triple-murder charge. I can't remember the last time I spoke to someone without knowing their name or background.

"I guess I had to see if it was real," I say. "A museum of nothing, you know, I thought it was a joke."

"It did make you laugh." The man's voice sounds friendly. Is it? Can I trust myself to $\rightarrow$ NATURE.COM

Follow Futures: Y @NatureFutures f go.nature.com/mtoodm know?

"Why did you come?" I ask.

He gestures at the empty wall in front of pects about me.

"I'm Tara," I say.

He holds out his hand, then grasps mine when I reach and miss. "Duke," he says. "It's a pleasure to meet you."

I'm not Tara and, somehow, I know he's not Duke. My head hurts from the eyestrain. Still, I'd like to stay for a while. 'Duke' and I will have to leave separately if we don't want to shatter the illusion.

But right now, it doesn't matter. In here, we can paint ourselves a new identity, Picasso morphing from blue to rose to crystal. We can be anyone we want when no one knows otherwise. Far from a Museum of Nothing, in this place, we're both the artists and the art..

Anna Zumbro lives in Washington DC. Her stories have appeared in Cricket, Daily Science Fiction, Grievous Angel and other publications. 